\author{
Witold Zalewski \\ Międzyuczelniany Instytut Muzyki Kościelnej, Kraków \\ Uniwersytet Papieski Jana Pawta II w Krakowie
}

\title{
Miejsce i rola solowej muzyki organowej w liturgii Kościoła rzymskokatolickiego
}

Wykorzystanie w liturgii solowej muzyki organowej stwarza dla organistów nie lada wyzwanie, a także nasuwa wiele wątpliwości i problemów. Ich przyczyn doszukiwać się można w wielu niedostatkach. Mogą to być m.in.: brak odpowiedniego instrumentu w kościele lub jego zły stan techniczny, brak odpowiedniej literatury organowej w biblioteczce organisty, nieznajomość dokumentów Kościoła na ten temat zarówno przez organistów, jak i duchownych, brak chęci do poszerzania swoich umiejętności zawodowych i wiedzy liturgicznej, a także brak zrozumienia ze strony pracodawcy na inicjatywy muzyka. „Możliwość ta [wykorzystanie literatury organowej - przyp. autora] nie jest zbyt często stosowana w ramach liturgii. Przyczynę stanowi najczęściej niedokształcenie organistów”1.

To chyba już nieaktualny mit, nietrudny do obalenia, mając na uwadze działające od lat na terenie wielu diecezji szkoły organistowskie, a przede wszystkim instytuty i zakłady muzyki kościelnej. Co roku absolwentami tych instytucji zostają wszechstronnie wykształceni muzycy kościelni, pełni wiary i nadziei, że lata ciąłych wyrzeczeń, wielogodzinnych ćwiczeń na instrumencie i nauki nie pójdą na marne. Już pierwsze kroki muzyków kościelnych brutalnie weryfikują ich oczekiwania i wyobrażenia. Ciąły pośpiech i spychanie na margines pozycji organisty w liturgii stopniowo gaszą w nich młodzieńczy zapał i energię. Dla niejednego pracodawcy liczy się tylko śpiew z ludem, schola gitarowa i ewentualnie chór parafialny...

Prawdą jest, że

nie ma nic podnioślejszego i milszego w świętych czynnościach, jak zgromadzenie, które wspólnie wyraża wiarę i pobożność. Dlatego pilnie należy popierać czynne uczestnictwo wiernych przejawiające się w śpiewie ${ }^{2}$.

1 I. Pawlak, Muzyka liturgiczna po Soborze Watykańskim II w świetle dokumentów Kościota, Lublin 2001, s. 271.

2 Święta Kongregacja Obrzędów, Instrukcja Musicam sacram [dalej: MS] 16. 
Zapewne dlatego organista postrzegany jest w kościele najczęściej jako osoba intonująca i podtrzymująca śpiew ludu! Dla wiernych natomiast dobry organista to ten, który ładnie śpiewa...

Jest to prawda, ale tylko częściowa! II Sobór Watykański przypomina bowiem o ważnej roli organów, instrumentu, którego „brzmienie ceremoniom kościelnym dodaje majestatu, a umysły wiernych podnosi do Boga i spraw niebieskich"3. W duchu tej reformy instrukcja Musicam sacram z roku 1967 potwierdza zacytowaną powyżej konstytucję o liturgii, jednocześnie rozszerzając jej myśli o stwierdzenie, że:

w Kościele łacińskim należy mieć $\mathrm{w}$ wielkim poszanowaniu organy piszczałkowe jako tradycyjny instrument muzyczny, którego brzmienie ceremoniom kościelnym dodaje majestatu, a umysły wiernych porywa do Boga i spraw niebieskich ${ }^{4}$.

Te najważniejsze posoborowe dokumenty nawiązują do stanowiska Kościoła na temat muzyki kościelnej z pierwszej połowy XX wieku, w której kluczową rolę odegrały motu proprio Piusa X (1903) oraz Musicae sacrae disciplina (1955). W tym drugim dokumencie czytamy:

pierwszeństwo przed wszelkimi instrumentami w świętych obrzędach mają organy. Ich brzmienie bowiem nadzwyczaj harmonizuje ze śpiewem i obrzędami sakramentalnymi dodając im wspaniałości i artyzmu, wzniosłością zaś swoją i słodyczą wzrusza serca wiernych, napełnia je radością i mocno pociąga ku Bogu i rzeczom wyższym5.

Jak należy rozumieć zatem - w świetle wymienionych wyżej dokumentów - rolę organów w dzisiejszej liturgii? Kiedy dodają one uroczystościom majestatu, a kiedy podnoszą umysły wiernych ku Bogu i sprawom niebieskim? Czy już sama ich obecność w liturgii wystarcza?

Otóż, jak przyjmuje się wyższość liturgii śpiewanej od recytowanej, tak samo należy rozumieć wyższosś liturgii śpiewanej przy wykorzystaniu organów od liturgii bez tego instrumentu. Można zatem przyjąć, że już sam udział królewskiego instrumentu w liturgii dodaje jej majestatu, a dodatkowo odpowiedni dobór głosów w organach czyni ją także okazalszą i donioślejszą (za przykład niech posłuży uroczyste Gloria grane i śpiewane w kościele pełnym wiernych na tutti w organach,

3 Konstytucja o liturgii świętej Sacrosanctum Concilium [dalej: KL] 120.

4 MS 62.

5 Encyklika Musicae sacrae disciplina [dalej: MSD] 29. 
a to samo grane przy użyciu głosów podstawowych i labialnych). Zazwyczaj jednak akompaniujące organy pełnią rolę drugorzędną. Wynika to już z samego zrozumienia terminu akompaniamentu, a przede wszystkim umiejscowienia śpiewu w liturgii: „Ponieważ zaś śpiew powinien zawsze mieć pierwszeństwo, to organy i inne instrumenty powinny tylko po prostu podtrzymywać go, a nigdy przygłuszać" ${ }^{6}$.

Nasuwa się następne pytanie: czy organy użyte jedynie do akompaniamentu liturgicznego mogą podnosić także umysły wiernych ku Bogu i sprawom niebieskim? Może być i tak! Na pewno jednak organiści poprzez niewłaściwy akompaniament, złą harmonię i nietrafianie w tonację przy dialogach mszalnych mogą ośmieszyć siebie i liturgię, a tym samym odwrócić wiernych od spraw niebieskich.

To raczej solowa muzyka organowa może zarówno uczynić liturgię bardziej dostojną, jak i przybliżyć lud Boży ku Bogu. Dokumenty kościelne są jednak bezwzględne - „gra solowa możliwa jest jedynie na początku, zanim kapłan przyjdzie do ołtarza, na ofiarowanie, podczas Komunii i na końcu"7.

Pierwszą sposobnością do zastosowania solowej muzyki organowej będzie rozpoczęcie liturgii. W zależności od różnych okoliczności moment pojawienia się przy ołtarzu celebransa może się znacznie wydłużyć, zależy to m.in.: od odległości od zakrystii do ołtarza, liczby uczestników procesji i wiernych w kościele. Ponieważ trudno będzie organiście oszacować czas tego przemarszu, próba wykonania solowego utworu jest dosyć ryzykowna i niekomfortowa, chyba że muzyk zna orientacyjny czas trwania dzieła i odpowiednio go przed liturgią rozpocznie. Musi mieć jednak na uwadze ewentualne jego skrócenie. Praktyka skracania utworów znana była już od czasów Frescobaldiego ${ }^{8}$. Docenia to także J. Erdman:

W praktyce liturgicznej cecha ta zawsze miała ważne znaczenie? . Kiedy muzyka sakralna wykonywana jest podczas nabożeństwa, winna ona być dostosowana do rytmu i wymogów liturgii. Pociąga to za sobą nierzadko

6 Pius X, Motu proprio Inter pastoralis officii sollicitudines [dalej: MP] 16.

7 MS 65.

8 W przedmowie G. Frescobaldiego do Toccate e partite d'intavolatura di cembalo (1615-1616) czytamy: „W toccatach wziąłem pod uwagę nie tylko to, że są pełne zróżnicowanych odcinków, ale również to, że każdy z tych odcinków może być grany oddzielnie jeden od drugiego; dlatego grający bez obowiązku skończenia wszystkich będzie mógł zakończyć, gdzie będzie uważał za stosowne”. Tekst i tłumaczenie: M. Szelest, Przemiany stylistyczne we wtoskiej muzyce organowej przetomu XVI i XVII stulecia, Kraków 2007, s. 298. Zob. także: S. Ferfoglia, Msza alternatim we wtoskiej i francuskiej muzyce liturgicznej XVII wieku, Kraków 2011, s. 69.

9 I. Pawlak, Muzyka liturgiczna po Soborze Watykańskim II w świetle dokumentów Kościota, Lublin 2001, s. 220; zob. J. Erdman, Możliwości wykorzystania literatury organowej we wspótczesnej liturgii, [w:] Muzyka sakralna, red. J. Masłowska, Warszawa 1998, s. 225. 
konieczność wykonywania tylko fragmentów dzieł, które powstały w czasach, kiedy czynne uczestnictwo wiernych w liturgii nie było przedstawiane jako źródło autentycznej duchowości chrześcijańskiej ${ }^{10}$.

Ważne jest bowiem zachowanie zasady nieprzedłużania liturgii, „ewentualne wykonanie dzieł muzycznych w postaci skróconej może być uzupełnione prezentacją ich w całości poza liturgią w formie koncertów muzyki sakralnej”"11. Rozpoczynając część muzyczną równo z dzwonkiem informującym o wyjściu celebransa z zakrystii, bardziej wskazana jest improwizacja jako wstęp do śpiewu wiernych niż wykonanie utworu organowego.

„Ponieważ w obecnym Mszale nie ma antyfony na ofertorium, a więc nie jest obligatoryjny śpiew, w niektórych okolicznościach można grą organową wypełnić czas obrzędu przygotowania darów" ${ }^{12}$. Jeśli jednak nie ma procesji z darami oraz okadzenia ołtarza, czas na muzykę w ogóle w tym miejscu sprawowanej liturgii jest niestety niewielki. Zazwyczaj wystarcza go na śpiew pieśni z ludem poprzedzony lub zakończony krótką improwizacją organową.

Dokumenty Kościoła pozwalają także na muzykę organową podczas Komunii św. Nie jest jednak sprecyzowane dokładnie, w którym momencie jej trwania - czy na początku, w trakcie, a może już po zakończeniu przyjmowania przez wiernych Komunii św. Zazwyczaj przyjmowaniu Pana Jezusa pod postacią Chleba przez wiernych towarzyszy śpiew. Organista po jego zakończeniu podejmuje niekiedy próbę wykonania solowego utworu organowego jako formę uwielbienia. Nie zawsze jednak z powodzeniem. I choć bliższy duchowi liturgii jest właśnie taki układ (ponieważ śpiew z ludem zastępuje antyfonę mszalną obowiązkową do recytacji), bezpieczniejsze i mniej stresujące dla muzyka jest odwrócenie kolejności, czyli najpierw utwór, potem śpiew z ludem. Potwierdzeniem takiego rozwiązania niech będą słowa ks. I. Pawlaka:

należy sobie życzyć, by prawo doczekało się dalszej reformy... Któż bowiem zaprzeczy pożytkowi, jaki można uzyskać z dobrej gry organowej w poszczególnych częściach liturgii, np. gdy towarzyszy ona procesji do Komunii św., podczas której nie zawsze istnieje możliwość wykonania śpiewu ${ }^{13}$.

${ }^{10}$ Kongregacja Kultu Bożego, Instrukcja o koncertach w kościołach [dalej: IKK] 5.

${ }^{11}$ IKK 6.

${ }^{12}$ A. Zając, Muzyka organowa dzisiaj. Rola i zadanie organisty w kościele, „Pro Musica Sacra”, t. V, 2008, s. 81.

${ }^{13}$ Komentarz do instrukcji, s. 38. Por. także I. Pawlak, Gra na instrumentach - muzyka liturgiczną?, „Liturgia Sacra” 1:1995, nr 4, s. 189; tenże, Muzyka liturgiczna po Soborze Watykańskim II..., dz. cyt., s. 81 . 
lub kardynała J. Ratzingera, który uważa, że „wielką muzykę odrzucono w imię „aktywnego uczestnictwa”, i pyta jednocześnie

czy rzeczywiście nie ma nic aktywnego w słuchaniu, w intuicyjnym pojmowaniu, we wzruszeniu? Czyż nie umniejsza się właśnie roli człowieka, każąc mu uczestniczyć w liturgii za pomocą wypowiadanych słów ${ }^{14}$ ?

Ostatnim momentem w liturgicznej celebracji Eucharystii stosownym dla solowej muzyki organowej jest zakończenie liturgii. Dobrze byłoby, aby każdy śpiew wieńczący Eucharystię odbywał się wspólnie z celebransem, tak aby zapobiec wcześniejszemu wychodzeniu wiernych z kościoła. Wszystko zaś po to, aby towarzysząca procesji wyjścia muzyka organowa po raz kolejny dodała uroczystego charakteru sprawowanym obrzędom ${ }^{15}$.

Osobnym zagadnieniem jest wykonanie solowej muzyki organowej w ciągu roku liturgicznego. Według instrukcji Musicam sacram ,gry solowej na instrumentach nie dopuszcza się w okresie Adwentu, Wielkiego Postu, w Triduum Wielkiego Tygodnia, oraz w Oficjum i we Mszy świętej za zmarłych"16. Jak twierdzi cytowany już autorytet w zakresie muzyki kościelnej, ks. I. Pawlak „«Post» od muzyki osłabia uroczystą liturgię w jej integralnej substancji, a bezduszne i fanatyczne podejście do niego godzi w samą istotę czynności liturgicznych" ${ }^{17}$. Należy docenić stanowisko Episkopatu Polski, który w swojej instrukcji z roku 1979 jest bardziej liberalny i mówi: „solowa gra na instrumentach zabroniona jest od zakończenia śpiewu hymnu Chwata na wysokości Bogu we Mszy Wieczerzy Pańskiej do zakończenia tego hymnu we Mszy Wigilii Paschalnej"18.

Reasumując: solowa muzyka organowa w liturgii Kościoła rzymskokatolickiego w Polsce możliwa jest niemalże przez cały rok kościelny z wyjątkiem czasu, kiedy organy w liturgi i zwyczajowo milkną. Niezrozumiały wydaje się zatem zapis w kalendarzu liturgicznym dla diecezji krakowskiej, w którym czytamy, że

gra na organach [w okresie Wielkiego Postu - przyp. autora] jest dozwolona tylko przy nabożeństwach pozaliturgicznych; przy wystawieniu Najśw.

\footnotetext{
${ }^{14}$ J. Ratzinger, Raport o stanie wiary, Kraków, s. 110n; I. Pawlak, Muzyka liturgiczna po Soborze Watykańskim II..., dz. cyt., s. 75.

15 Zob. KL 120.

${ }^{16}$ MS 66.

${ }^{17}$ I. Pawlak, Funkcje muzyki w liturgii, [w:] Śpiew wiernych w odnowionej liturgii, Opole 1993, s. 67; tenże, Muzyka liturgiczna po Soborze Watykańskim II..., dz. cyt., s. 76.

${ }^{18}$ Instrukcja Episkopatu Polski o muzyce liturgicznej po Soborze Watykańskim II, 19.
} 
Sakramentu; dla podtrzymania śpiewu wiernych w czasie sprawowania liturgii; w niedzielę „Laetare”, w święta i uroczystości oraz przy nadzwyczajnych obchodach ${ }^{19}$.

Uprasza się zatem liturgistów przygotowujących kalendarz dla diecezji krakowskiej o konsultację z Komisją Muzyki Kościelnej, tak aby w przyszłości uniknąc rozpowszechnianiu nierzetelnych informacji dotyczących zastosowania organów w liturgii.

Skąd się zatem bierze brak solowej muzyki organowej w sprawowanej Eucharystii? Wydaje się, że wina leży pośród osób zaangażowanych w liturgię, czyli muzyków i duchownych. Zaczynając od organistów - mają oni rację, gdy uważają, że

muzyka jako sztuka do swego rozwoju nie potrzebuje liturgii, choć bez niej niewątpliwie stałaby się uboższa. Natomiast liturgia potrzebuje muzyki, gdyż bez tego znaku nie istnieje w swej świątecznej formie ${ }^{20}$.

Często jednak zapominają o roli muzyki w liturgii i o tym, że

trzeba potępić jako największe nadużycie, aby w czynnościach kościelnych liturgia występowała drugorzędnie, jakby na usługach muzyki, wówczas kiedy muzyka jest po prostu tylko częścią składową liturgii i jej pokorną sługą ${ }^{21}$.

Idą na łatwiznę i nie dbają o piękno liturgii choć „muzyka ze swej istoty, chcąc nie chcąc, jest także ozdobą liturgii. Piękno bowiem stanowi jeden z istotnych jej elementów”22. Nie ćwiczą na organach, nie poszerzają repertuaru, ulegają rutynie, choć

każdy utwór organowy, najbardziej artystycznie wyrafinowany i wykonawczo skomplikowany, o ile uwzględnia ducha liturgii, a organista jest w stanie dobrze go wykonać, może mieć zastosowanie podczas liturgicznej celebracji ${ }^{23}$.

19 Zob. Kalendarz liturgiczny archidiecezji krakowskiej na rok 2012, Kraków 2011, s. 73.

${ }^{20}$ I. Pawlak, Muzyka liturgiczna po Soborze Watykańskim II..., dz. cyt., s. 97.

${ }^{21}$ MP VII. Rozmiary kompozycji liturgicznych.

${ }^{22}$ I. Pawlak, Muzyka liturgiczna po Soborze Watykańskim II..., dz. cyt., s. 74; H. H. Eggebrecht, O pięknie muzycznym, [w:] C. Dahlhaus, H. H. Eggebrecht, Co to jest muzyka?, Warszawa 1992, s. 151.

${ }^{23}$ A. Zając, Muzyka organowa dzisiaj. Rola i zadanie organisty w kościele, „Pro Musica Sacra”, t. V, 2008, s. 79. 
Od księży oczekiwać należy większego zaufania i szacunku wobec swoich organistów, bowiem „w odbiorze wiernych muzyka organowa wykonywana w kościołach zarówno podczas liturgii, jak i w czasie koncertów organowych jest bardzo ceniona i nieodłącznie kojarzy się z domeną sacrum" 24. Duchowni powinni pamiętać, że

w dobie, gdy edukacja muzyczna jest wypierana ze szkoły, gdzie było jej naturalne środowisko, przed Kościołem stoi wielkie zadanie kształtowania i edukowania poprzez muzykę tych, którzy uczestniczą w liturgiii ${ }^{25}$.

Powinni także zrozumieć, że „taka praktyka przyczynia się bardzo do wyrobienia właściwego smaku muzycznego wiernych w parafiach i podnoszenia ich kultury muzycznej”26. A to wszystko w połączeniu z pięknym wystrojem kościoła, mądrym kazaniem, empatią wobec wiernych, jednoczy społeczność parafialną i przekłada się na frekwencję podczas nabożeństw. Niech zatem czcigodni księża proboszczowie nie szczędzą środków na strojenie i utrzymanie organów, a organiści poprzez muzykę organową uczynią liturgię jeszcze piękniejszą i dostojniejszą.

\section{Place and role of organ music in Roman Catholic liturgy}

Incorporating solo organ music in Roman Catholic liturgy may constitute a challenge for some organists. The very issue may raise some doubts and problems. "This usually results from insufficient education of professional organists" ${ }^{\prime 27}$. Fortunately, this is an invalid myth, easy to refute, bearing in mind the years of work and impact made by numerous Organist schools operating within dioceses, as well as Institutes of Church $\mathrm{Mu}$ sic. Great numbers of broadly educated church musicians graduate from these schools every year. Unfortunately, constant rush and marginalization of the organist's position in liturgy tend to discourage young organists. The majority of employers seem to be focusing on singing with the people, small choirs with the accompaniment of guitar or, possibly, parish choirs themselves.

\footnotetext{
24 Tamże, s. 82.

${ }^{25}$ R. Tyrała, Czy dziśs w kościele potrzebna jest dobra muzyka, „Musica Sacra” 3, Prace Specjalne 73, Gdańsk 2007, s. 18.

${ }_{26}$ Tamże.

27 I. Pawlak, Muzyka Liturgiczna, po Soborze Watykańskim II..., dz. cyt., s. 271.
} 
It is true that we "should intently urge churchgoers to actively participate in liturgy in the form of singing" ${ }^{28}$. This is probably why the church organist is usually considered the person to set the proper tone and keep up the singing in the church! For churchgoers, however, a good organist is the one who sings well...

This is true, but only partially. The Second Vatican Council reminds us of the importance of the organ, an instrument "adding a grandeur dimension to church ceremonies, raising the souls and minds of believers to God and heavenly matters" 29 . How should we then consider the role of the organ in the liturgy of today, in the light of post-council documents? It may be assumed that the very participation of this majestic instrument in the liturgy adds grandeur, although pipe organ accompanying churchgoers singing tends to perform a secondary role.

It is rather solo organ music which could make the Eucharist more dignified and grandly. It could also bring God's people closer to God. Church documents are, however, very rigid in this matter - "solo music shall only be possible in the beginning, before the chaplain attends the altar, during the oblation, during the Communion and in the end of the mass" 30 .

Organ music performances during the Lent seem to be a separate issue since they are strictly prohibited by some church documents. In the opinion of priest I. Pawlak "fasting" from music reduces the liturgy in its integral substance, and a heartless or fanatic approach to fasting undermines the essence of liturgical activities" ${ }^{31}$. Therefore, all church musicians are optimistic to witness the changing stance of the Polish Episcopal Conference, which, in its new Instructions issued in 1979, adopted a more liberal approach.

Stowa kluczowe muzyka w liturgii, organy, muzyka organowa

Keywords music in the Liturgy, organ, organ music

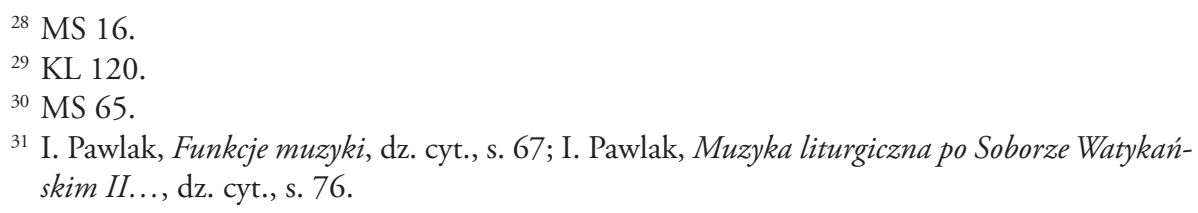

